\title{
Growth of Chlorella vulgaris and Nannochloris oculata in effluents of Tilapia farming for the production of fatty acids with potential in biofuels
}

\author{
Yesica I. Ferrer-Álvarez ${ }^{1}$, Luis A. Ortega-Clemente ${ }^{1 *}$, Ignacio A. Pérez-Legaspi ${ }^{1}$, Martha P. \\ Hernández-Vergara ${ }^{1}$, Paula N. Robledo-Narváez ${ }^{2}$, Elvira Ríos-Leal ${ }^{3}$ and \\ Héctor M. Poggi-Varaldo ${ }^{3}$
}

${ }^{1}$ Instituto Tecnológico de Boca del Río, División de Estudios de Posgrado e Investigación, Carr. Veracruz-Cordoba km. 12, P. O. Box 94290, Boca del Río, Veracruz, México.

${ }^{2}$ Instituto Tecnológico Superior de Tierra Blanca, Av. Veracruz S/N Esq. Héroes de Puebla, Colonia Pemex, Tierra Blanca, P. O. Box 95180, Veracruz, México.

${ }^{3}$ Centro de Investigación y de Estudios Avanzados del I. P. N., Department of Biotechnology \& Bioengineering, Environmental Biotechnology and Renewable Energies R\&D Group, P. O. Box 14-740, 07000, México D. F., México.

Received 13 January, 2015, Accepted 15 May, 2015

\begin{abstract}
The use of microalgae in wastewater treatment and its biotechnological exploitation for the production of biofuels is a potential environmental application. Some species of microalgae are notable due to their lipid composition and fatty acid profile suitable for biofuel production. During the present study, a factorial $2^{3}$ experimental design was conducted, which assessed three factors: i) two species of microalgae (Chlorella vulgaris and Nannochloris oculata), ii) two types of culture media [wastewater of tilapia farming (WTF) and bold's basal medium (BB)], and iii) two types of lighting (multi-LED lamps and white light). Microalgae were inoculated in photobioreactors in $6 \mathrm{~L}$ of medium (WTF or BBM) at an initial concentration of $1.0 \times 10^{6}$ cells $\mathrm{ml}^{-1}$ at $20 \pm 2^{\circ} \mathrm{C}$. The highest average cell density as well as the highest productivity of biomass observed in the treatments was $C$. vulgaris treatment in BBM and multi-LED lighting $\left(8.83 \times 10^{7}\right.$ cells $\mathrm{I}^{-1}$ and $0.0854 \mathrm{~g} \mathrm{I}^{-1} \mathrm{~d}^{-1}$, respectively). Although the majority of lipid productivity was obtained in the exponential phase of $N$. oculata cultivated in multi-LEDs in both treatments (BBM with $58 \%$ and WTF with $52 \%$ ), cultivation of both species was generally maintained in WTF and were those that presented the major lipid productivity $\left(2-18 \mathrm{mg} \mathrm{l}^{-1} \mathrm{~d}^{-1}\right)$ in comparison with those cultivated in BBM. Palmitic, stearic, oleic, linoleic, linolenic and eicosanoic (C16-C20) fatty acids were present in both species of microalgae in concentrations between 26 and $74 \%$. Based on the results of the present study, we conclude that cultivation of $\boldsymbol{N}$. oculata and/or $\boldsymbol{C}$. vulgaris in WTF illuminated with multi-LEDs is an economic and sustainable alternative for biodiesel production because it can represent up to $58 \%$ of lipids with a fatty acid profile optimal up to $74 \%$ of the total fatty acids.
\end{abstract}

Key words: Chlorella vulgaris, Nannochloris oculata, production of fatty acids, wastewater of tilapia farming, production of biofuels.

\section{INTRODUCTION}

During the last few decades, an energy crisis associated with depletion of irreversible traditional fossil fuel sources is being recognized worldwide. We are aware that its use as a primary source of energy is unsustainable and 
contributes to the accumulation of greenhouse gases, which causes global warming and a permanent source of atmospheric environmental pollution (Ahmad et al., 2011; Amaro et al., 2011). Likewise and with current trends of fossil energy consumption, worldwide oil reserves could be depleted by the year 2050 (Demirbas, 2011; Chen et al., 2013). Because of this, international trends of power generation and environmental protection are derived from the research and development of renewable, economically competitive and environmentally friendly alternative sources of energy (Ahmad et al., 2011; Chen et al., 2013; DeJong et al., 2013). Liquid fuels derived from plant matter (also called biofuels) are an alternative to the generation of sustainable energy. In comparison with other renewable forms (for example, wind, tidal and solar), these allow storage for long periods of time due to their chemical structure and can be used in addition to the traditional forms in engines and existing transport infrastructure after mixing to varying degrees with diesel oil (Singh and Gu, 2010; Amaro et al., 2011). The choice of biomass as feedstock for the production of energy depends on social, environmental, economic and industrial factors in addition to its availability and cost. However, generation of biodiesel from grain legume entails the use of large tracts of arable land and fresh water for cultivation. Also, there is the possible competition with food production of direct use to man or animal in addition to seasonal and geographical variations that also affect productivity as well as the use of herbicides and the consequent environmental pollution (Chen et al., 2013).

Therefore, production of biodiesel from microalgae is an important option that should be evaluated as an alternative for the generation of biofuels. This also seems to be a renewable source of fuel that can satisfy the global demand for transport fuels (Chisti, 2007; Demirbas, 2011) but also has the potential to generate large volumes of feedstock without affecting the food supply (Rosch et al., 2012). Microalgae as biofuel producers have different advantages such as high productivity, accumulation of lipids, and ability to grow in wastewater. In addition, microalgae have a higher productivity per area and have the ability to grow in nonarable lands with water unsuitable for agriculture, using $\mathrm{CO}_{2}$ and other industrial waste (Delrue et al., 2012; Lohrey et al., 2012; Chen et al., 2013; Sánchez et al., 2015). A scarcely exploited alternative for the generation of microalgal biomass is waste water of production aquaculture, which may have as an advantage the biological water treatment and reinstatement into the aquaculture system. This allows the nutrition of microalgae using organic compounds (nitrogen and phosphorus) available in these effluents (Mata et al., 2010; Chávez-Crooker and Obreque-Contreras, 2010; Marinho-Soriano et al., 2011). It is reported that algae produce more lipids in a stress environment or under unfavorable conditions compared to optimal growth conditions. During optimal growth conditions, algae synthesize fatty acids mainly for esterification to glycerol in membrane lipids, which constitute $\sim 5-20 \%$ of their dry weight. However, under conditions of stress, by limiting nitrogen or another component, microalgae have a very high production of lipids that can reach up to $77 \%$ of its dry weight (Mata et al., 2010; Kirrolia et al., 2013; Josephine et al., 2015).

The present study assessed the production of fatty acids in two freshwater microalgae Chlorella vulgaris and Nannochloris oculata cultured in Wastewater of Tilapia Farming (WTF) and Bold's Basal Medium (MBB) using two lighting systems in order to determine their potential for the generation of biofuels.

\section{MATERIALS AND METHODS}

\section{Strains and growth medium}

C. vulgaris (code: CLV2) and N. oculata (code: LB2194), were obtained from the collection of the Department of Aquaculture of the Center of Scientific Research and from the Center for Higher Education and Teaching (CICESE) and from the Collection of the University of Texas (UTEX), respectively. Strains were maintained in sterile BBM in flasks of $125 \mathrm{ml}$ under controlled laboratory conditions (Bischoff and Bold, 1963; Nichols, 1973; Andersen, 2005) during a $24 \mathrm{~h}$ photoperiod of light without aeration and temperature of $18^{\circ} \mathrm{C}$ in a light chamber at $18.5 \mu \mathrm{mol} \mathrm{m} \mathrm{m}^{-2} \mathrm{~s}^{-1}$. The large-scale culture of $C$. vulgaris and $N$. oculata was carried out in four $1000 \mathrm{ml}$ Erlenmeyer flasks with $750 \mathrm{ml}$ of sterile BBM and 100 $\mathrm{ml}$ of inoculum suspension $\left(1.0 \times 10^{6}\right.$ cells $\left.\mathrm{ml}^{-1}\right)$ for reseeding. Lighting conditions were $24 \mathrm{~h}$ photoperiods with constant aeration at a temperature of $18^{\circ} \mathrm{C}$ in a light intensity of $79.88 \mu \mathrm{mol} \mathrm{m} \mathrm{m}^{-2} \mathrm{~s}^{-1}$.

\section{Photobioreactors, treatment systems}

For the cultivation of microalgae, C. vulgaris and N. oculata, 16 photobioreactors were used, which consisted of $15 \times 45 \mathrm{~cm}$ acrylic hexagonal units with a capacity of $8 \mathrm{~L}$ and closed completely by having the top drilled. Two $5 \mathrm{~mm}$ glass tubes were placed, the first to provide oxygen and homogenize cultivation using a pump. The second glass tube was used to take samples to monitor the cultivation. During the study, photobioreactors were placed in two structures in order to have two modules, which are illuminated individually through the following schemes: module 1 lighting the

${ }^{*}$ Corresponding author. E-mail: alfclemen2002@hotmail.com, alfclemen2002@yahoo.com.mx.

Author(s) agree that this article remains permanently open access under the terms of the Creative Commons Attribution License 4.0 International License

Abbreviations: BBM, Bold's basal medium; WTF, wastewater tilapia farming; Nn, Nannochloris oculata; Ch, Chlorella vulgaris; LED, multi-LED lighting; WL, white lights. 


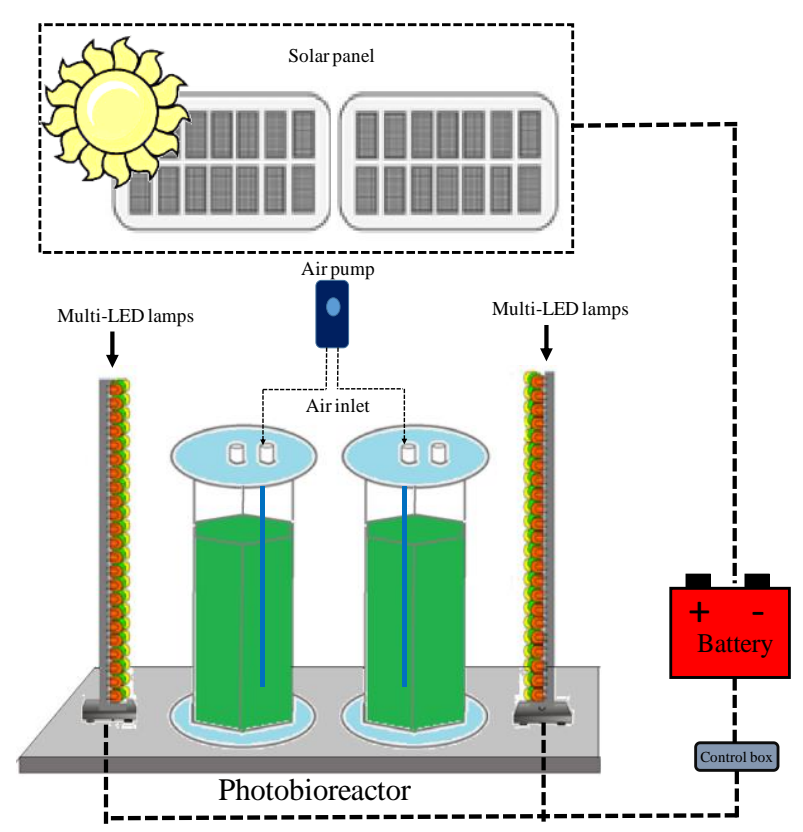

(a)

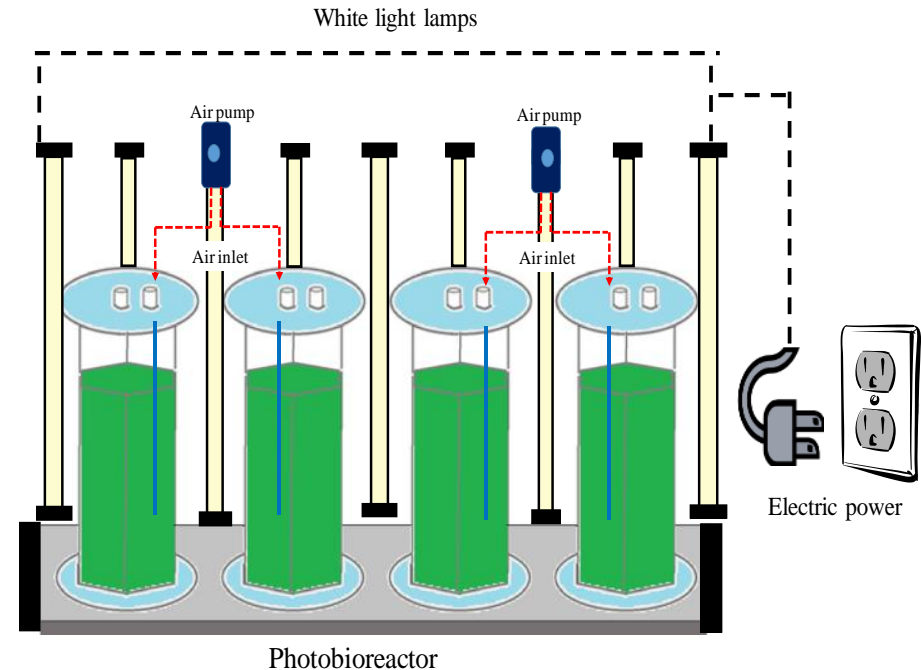

(b)

Figure 1. Types of lighting in farming systems. (a) Multi-LED lamps. (b) White light lamps.

photobioreactors generated from four multi-LED reflectors (RF240HFS 30W) energized by two batteries (Surrette S-600 deep cycle $6 \mathrm{~V}, 450 \mathrm{Ah}$ ) connected to five solar panels (polycrystalline $145 \mathrm{~W}$ modules placed in the upper part of the roof of the LLF). The second module consisted of four $40 \mathrm{~W}$ white lights energized with direct current $(220 \mathrm{~V})$. Both systems (Figure 1) maintained a light intensity of $79.88 \mu \mathrm{mol} \mathrm{m} \mathrm{m}^{-2} \mathrm{~s}^{-1}$.

\section{Experimental design, sampling and analyses}

The experiment consisted of a $2^{3}$ factorial design, where three factors were evaluated: A) type of microalgae, B) type of culture medium, and $\mathrm{C}$ ) type of lighting at two levels each (8 treatments in total, with a replica by treatment). The experimental units (16 photobioreactors) were then added to $6 \mathrm{~L}$ of the microalgae culture medium corresponding to each treatment: eight photobioreactors with sterile BBM (control) prepared previously according to the specifications by Nichols (1973) and the other eight photobioreactors with sterile WTF collected from a pond cultivation of opencast tilapia located at the Instituto Tecnológico de Boca del Rio. These were previously filtered through a $100 \mu \mathrm{m}$ packed mesh column for phytoplankton with cotton and polyester fiber. The water was incorporated into the respective photobioreactors and disinfected using $0.8 \mathrm{ml} \mathrm{l}^{-1}$ of $\mathrm{NaClO}$ and neutralized with $0.75 \mathrm{~g} \mathrm{l}^{-1}$ of $\mathrm{Na}_{2} \mathrm{~S}_{2} \mathrm{O}_{3} .5 \mathrm{H}_{2} \mathrm{O}$ for $2 \mathrm{~h}$ under continuous aeration. The initial concentration of $\mathrm{NO}_{2}-\mathrm{N}, \mathrm{NO}_{3}-\mathrm{N}, \mathrm{NH}_{3}-\mathrm{N}$ and $\mathrm{PO}_{4}^{-3}$ in WTF was determined (1, 8.4, 0.31 and $1.5 \mathrm{mg} / \mathrm{l}$, respectively) using an HANNA Multiparameter (Model HI83099). Each culture medium was inoculated separately with $1.0 \times 10^{6}$ cells $\mathrm{ml}^{-1}$ of $C$. vulgaris and $N$. oculata. The volume of the inoculum to be used was determined by cell count in a Neubauer chamber (Pica-Granados et al., 2004) using the following equation:

$V_{2}=\frac{\left(C_{1} \cdot V_{1}\right)}{C_{2}}$
Where $\mathrm{V}_{1}=$ volume of reactor operation $(6000 \mathrm{ml}), \mathrm{C}_{1}=$ initial cell density in the reactor $\left(1.0 \times 10^{6}\right.$ cells $\left.\mathrm{ml}^{-1}\right), \mathrm{V}_{2}=$ volume of inoculum required for the reactor $(\mathrm{ml})$, and $\mathrm{C}_{2}=$ cell density of the inoculum at the time of inoculation of the reactor (cells $\mathrm{ml}^{-1}$ ).

Duration of the culture was 10 days at $20 \pm 2^{\circ} \mathrm{C}$. Light intensity of $79.88 \mu \mathrm{mol} \mathrm{m} \mathrm{m}^{-2} \mathrm{~s}^{-1}$ with multi-LED lamps or white light was used. Cell density (cells $\mathrm{ml}^{-1}$ ), lipid content $(\%)$, biomass productivity $\left(\mathrm{g} \mathrm{I}^{-1}\right.$ $\mathrm{d}^{-1}$ ), lipid productivity $\left(\mathrm{mg} \mathrm{l}^{-1} \mathrm{~d}^{-1}\right)$ and fatty acid quantification (\%) were evaluated. All results were expressed as mean \pm standard deviation. Statistical analysis was done using analysis of variance (ANOVA); $\mathrm{P}<0.05$ was accepted as statistically significant. Stat Soft, Inc. (2004) STATISTICA V.7 was used for analysis. A $400 \mathrm{ml}$ sample was used from treatment in the exponential (sixth day) and stationary (eighth day) phases based on growth kinetics. Samples were then filtered to gravimetrically determine dry and wet weight of the biomass. Once dried, samples were taken. We then proceeded to lipid extraction using the Soxhlet method with a mixture of chloroform/ methanol (1:2 v/v) (Halim et al., 2012). The product of the extraction was considered as the lipid content per species and treatment which, after being weighed, was stored in amber vials for later quantification of fatty acid profiles. For quantification of fatty acids, esterification or derivatization of the lipid fraction of the samples was carried out with the addition of $2.63 \mathrm{~g}$ of $\mathrm{KOH}, 30 \mathrm{ml}$ of methanol and $10 \mathrm{ml}$ of water. Evaporation was carried out and cooled to room temperature. Thirty $\mathrm{ml}$ of $\mathrm{HCl}$ was added to $3 \%$ in methanol and again evaporated to salt formation. The sample was rinsed with $20 \mathrm{ml}$ of distilled water and placed in a separation funnel to which $30 \mathrm{ml}$ of hexane was added. The sample was stirred for 1 min and then left to decant to obtain two phases and to scrape the precipitate. The supernatant was heated $\left(40^{\circ} \mathrm{C}\right)$ to evaporate the solvent residues and subsequently diluted to $200 \mu \mathrm{l}$. Samples were finally stored in amber vials. The supernatant was heated $\left(40^{\circ} \mathrm{C}\right)$ to evaporate the residue of the solvent and subsequently gauged to $200 \mu \mathrm{l}$ to finally keep the samples in amber vials (Lepage and Roy, 1984). Fatty acids were identified and quantified with a gas chromatograph (Perkin Elmer, Model Autosystem, Flame ionization) 
Table 1. Cell density average for Nannochloris oculata and Chlorella vulgaris according to the different treatments.

\begin{tabular}{|c|c|c|c|}
\hline \multirow{2}{*}{ Microalgae strains } & \multirow{2}{*}{ Light conditions } & Basal bold's medium & Wastewater tilapia farming \\
\hline & & \multicolumn{2}{|c|}{ Cell density (cells $\mathrm{ml}^{-1}$ ) } \\
\hline Nannochloris oculata & $\begin{array}{l}\text { Multi-LED } \\
\text { White light }\end{array}$ & $\begin{array}{l}2.52 \times 10^{7} \pm 1.12 \times 10^{7} \\
6.27 \times 10^{7} \pm 1.02 \times 10^{7}\end{array}$ & $\begin{array}{l}4.75 \times 10^{7} \pm 9.63 \times 10^{6} \\
4.52 \times 10^{7} \pm 1.17 \times 10^{7}\end{array}$ \\
\hline Chlorella vulgaris & $\begin{array}{l}\text { Multi-LED } \\
\text { White light }\end{array}$ & $\begin{array}{l}8.83 \times 10^{7} \pm 1.25 \times 10^{7} \\
6.54 \times 10^{7} \pm 1.04 \times 10^{7}\end{array}$ & $\begin{array}{l}5.63 \times 10^{7} \pm 1.06 \times 10^{7} \\
3.43 \times 10^{7} \pm 9.91 \times 10^{6}\end{array}$ \\
\hline
\end{tabular}

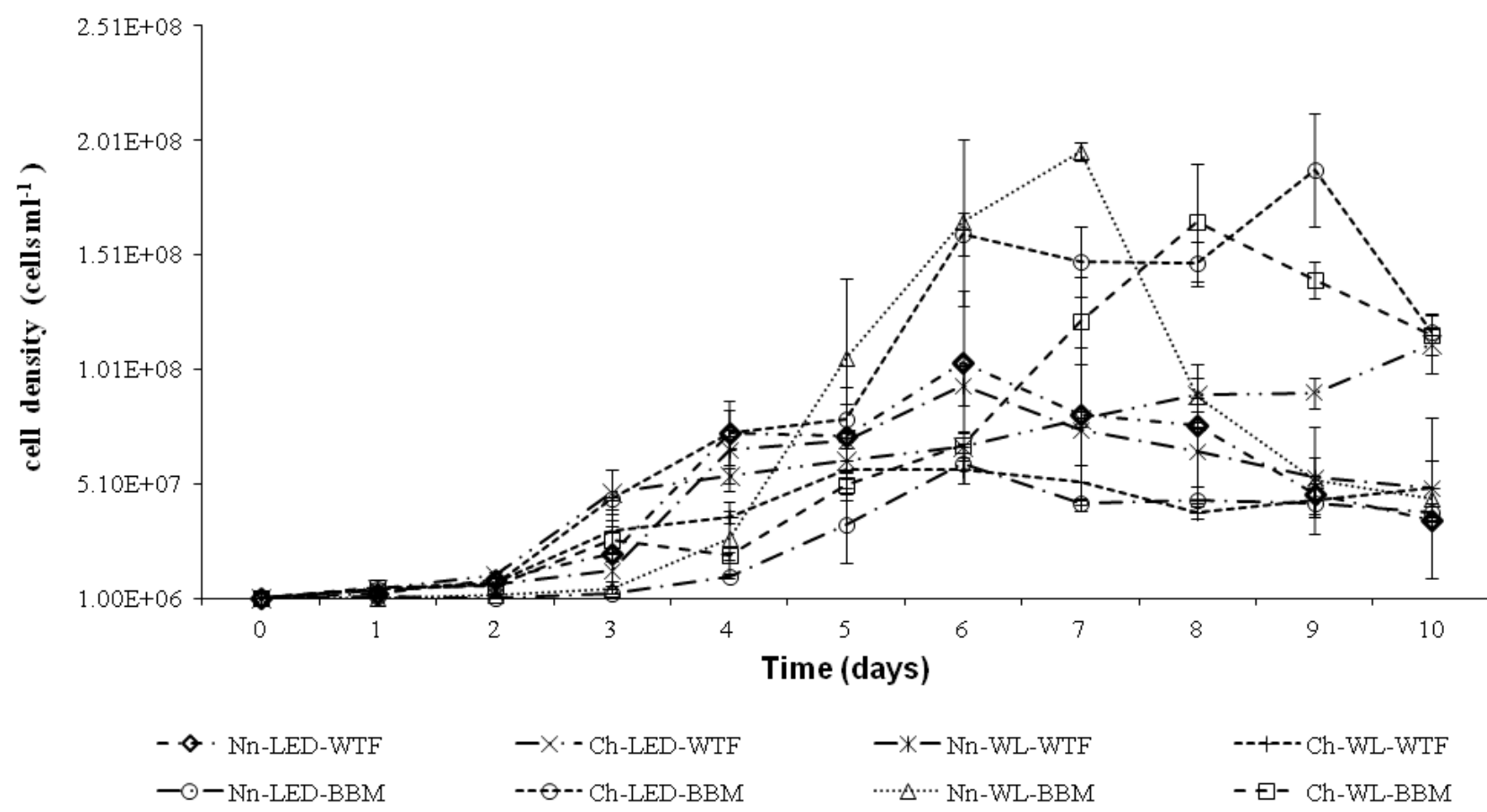

Figure 2. Comparison of cell density of Nannochloris oculata (Nn) and Chlorella vulgaris (Ch) in Wastewater Tilapia Farming (WTF) and Bold's Basal Medium (BBM) in multi-LED lighting (LED) and white lights (WL).

with an INNOWax capillary column $(30 \mathrm{~m}$ in length $\times 0.320 \mathrm{~mm}$ in diameter). Nitrogen $\left(\mathrm{N}_{2}\right)$ was used as carrier gas. The injector temperature was $250^{\circ} \mathrm{C}$ and the detector was $300^{\circ} \mathrm{C}$. Oven temperature was $150^{\circ} \mathrm{C}(4 \mathrm{~min})$ with a ramp of $5^{\circ} \mathrm{C} \mathrm{min}^{-1}$ to $190^{\circ} \mathrm{C}$ with a ramp of $2^{\circ} \mathrm{C} \min ^{-1}$ to $250^{\circ} \mathrm{C}(11 \mathrm{~min})$. The injection volume was $2 \mu \mathrm{l}$ per sample.

\section{RESULTS}

The results of this study indicate that, in general, the cultivations had a continuous and efficient growth in all tested treatments. It was observed that type of microalgae and type of culture medium as well as all the interactions among the effects were significant $(P<0.05)$. However, the type of lighting had no effect on cell growth. Except for treatment where the microalga $N$. oculata was under BBM white light illumination, most of the microalgae in the different treatments reached the exponential phase between the fifth and sixth day, whereas the first required 7 days and attained a cell density significantly $(P=0.00004)$ higher than that achieved by other algae $\left(1.96 \times 10^{8}\right.$ cells $\left.\mathrm{ml}^{-1}\right)$ under study (Figure 2). The most efficient average cell density was presented during cultivation of $C$. vulgaris in BBM with multi-LED lighting $\left(8.83 \times 10^{7}\right.$ cells $\left.\mathrm{ml}^{-1}\right)$, whereas the less efficient average cell density is presented in the same species in the WTF with white light. The highest average density of $N$. oculata was obtained in BBM with white light illumination $\left(6.27 \times 10^{7}\right.$ cells $\left.\mathrm{ml}^{-1}\right)$, significantly higher than that achieved with the same microalgae but with WTF under the same lighting conditions (Table 1). The total biomass productivity of $C$. vulgaris that occurred during the study regardless of the treatment was in a range of $0.031-0.085 \mathrm{~g} \mathrm{I}^{-1} \mathrm{~d}^{-1}$, whereas for $N$. oculata it was $0.014-0.057 \mathrm{~g} \mathrm{I}^{-1} \mathrm{~d}^{-1}$, presenting significant differences between types of microalgae (Table 2). This 
Table 2. Percent lipids, productivity of biomass and lipids of Nannochloris oculata and Chlorella vulgaris in WTF and BBM under two lighting conditions.

\begin{tabular}{|c|c|c|c|c|c|c|}
\hline $\begin{array}{l}\text { Microalgae } \\
\text { strains }\end{array}$ & $\begin{array}{l}\text { Culture } \\
\text { media }\end{array}$ & $\begin{array}{l}\text { Light } \\
\text { conditions }\end{array}$ & $\begin{array}{l}\text { Growth } \\
\text { phase }\end{array}$ & $\begin{array}{l}\text { Lipids } \\
\text { (\%) }\end{array}$ & $\begin{array}{l}\text { Biomass } \\
\text { productivity } \\
\left(\mathrm{g} \mathrm{l}^{-1} \mathrm{~d}^{-1}\right)\end{array}$ & $\begin{array}{l}\text { Lipids productivity } \\
\qquad\left(\mathrm{mg} \mathrm{l}^{-1} \mathrm{~d}^{-1}\right)\end{array}$ \\
\hline \multirow{8}{*}{$\begin{array}{l}\text { Nannochloris } \\
\text { oculata }\end{array}$} & \multirow{4}{*}{$\begin{array}{l}\text { Bold's basal } \\
\text { medium }\end{array}$} & \multirow[t]{2}{*}{ Multi-LED } & Exponential & $57.80 \pm 10.14$ & $0.0141 \pm 0.0002$ & $8.1786 \pm 5.7579$ \\
\hline & & & Stationary & $28.90 \pm 5.13$ & $0.0313 \pm 0.0004$ & $9.0313 \pm 1.5026$ \\
\hline & & \multirow[t]{2}{*}{ White light } & Exponential & $6.21 \pm 0.19$ & $0.0357 \pm 0.0115$ & $2.2083 \pm 0.6482$ \\
\hline & & & Stationary & $10.21 \pm 0.23$ & $0.0571 \pm 0.0074$ & $5.8438 \pm 0.8839$ \\
\hline & \multirow{4}{*}{$\begin{array}{l}\text { Wastewater of } \\
\text { tilapia farming }\end{array}$} & \multirow[t]{2}{*}{ Multi-LED } & Exponential & $51.57 \pm 7.22$ & $0.0205 \pm 0.0025$ & $10.6071 \pm 0.2020$ \\
\hline & & & Stationary & $33.34 \pm 0.34$ & $0.0279 \pm 0.0088$ & $7.1875 \pm 3.0273$ \\
\hline & & \multirow[t]{2}{*}{ White light } & Exponential & $42.49 \pm 11.73$ & $0.0219 \pm 0.0009$ & $9.2500 \pm 2.1802$ \\
\hline & & & Stationary & $25.43 \pm 3.36$ & $0.0320 \pm 0.0047$ & $7.9688 \pm 0.1105$ \\
\hline \multirow{8}{*}{$\begin{array}{l}\text { Chlorella } \\
\text { vulgaris }\end{array}$} & \multirow{4}{*}{$\begin{array}{l}\text { Bold's basal } \\
\text { medium }\end{array}$} & \multirow[t]{2}{*}{ Multi-LED } & Exponential & $27.66 \pm 5.72$ & $0.0459 \pm 0.0028$ & $12.6250 \pm 1.8435$ \\
\hline & & & Stationary & $21.04 \pm 4.99$ & $0.0854 \pm 0.0055$ & $17.8281 \pm 3.1157$ \\
\hline & & \multirow[t]{2}{*}{ White light } & Exponential & $34.94 \pm 2.36$ & $0.0384 \pm 0.0015$ & $13.3958 \pm 0.3830$ \\
\hline & & & Stationary & $22.41 \pm 2.18$ & $0.0543 \pm 0.0132$ & $11.3750 \pm 3.6681$ \\
\hline & \multirow{4}{*}{$\begin{array}{l}\text { Wastewater of } \\
\text { tilapia farming }\end{array}$} & \multirow[t]{2}{*}{ Multi-LED } & Exponential & $34.75 \pm 2.31$ & $0.0316 \pm 0.0033$ & $10.6429 \pm 0.4293$ \\
\hline & & & Stationary & $27.03 \pm 4.99$ & $0.0456 \pm 0.0061$ & $12.5000 \pm 2.1802$ \\
\hline & & \multirow[t]{2}{*}{ White light } & Exponential & $39.38 \pm 6.63$ & $0.0446 \pm 0.0080$ & $17.2917 \pm 0.1768$ \\
\hline & & & Stationary & $34.96 \pm 4.94$ & $0.0401 \pm 0.0021$ & $13.3958 \pm 0.3830$ \\
\hline
\end{tabular}

may be due to the fact that microalgal biomass productivity is directly dependent on the species studied and on culture conditions (Chojnacka and MarquezRocha, 2004; Simionato et al., 2013). On the other hand, the results show that the highest lipid content was reached with $N$. oculata under multi-LED lighting in BBM and WTF (58 and $52 \%$, respectively) in the exponential growth phase. Moreover, lipid productivity for both species was variable, according to medium as well as to type of lighting, reaching 2-18 $\mathrm{mg} \mathrm{I}^{-1} \mathrm{~d}^{-1}$ productivities. $C$. vulgaris presented the highest productivity for both culture media (BBM and WTF). However, for C. vulgaris in BBM with multi-LED lighting, the highest productivity was in the stationary phase $\left(17.83 \mathrm{mg} \mathrm{l}^{-1} \mathrm{~d}^{-1}\right)$ unlike in WTF with white light as lighting was in the exponential phase $\left(17.30 \mathrm{mg} \mathrm{l}^{-1} \mathrm{~d}^{-1}\right)$. Lipid productivity depends mainly on the type of microalgae, type of culture medium, lighting conditions and growth phase. Lipid content was similar to that achieved by $C$. vulgaris in WTF with white lighting of $37 \%$ with an average biomass productivity of $0.04 \mathrm{~g} \mathrm{l}^{-1} \mathrm{~d}^{-1}$. For cultivations in WTF as a stress condition for its limitation of nitrogen compared with BBM, results show that for both microalgae, the percentage and lipid productivity for WTF were higher (25-42\%) than in MBB $(6-35 \%)$, mainly in those treatments using white light illumination (Table 2). In addition, $N$. oculata and $C$. vulgaris showed the highest concentration of mono and polyunsaturated oleic, linoleic, palmitic, stearic, eicosanoic, arachidonic and eicosapentaenoic fatty acids in their lipid composition with fractions of $2-43 \%$ and up to $75 \%$ total (Table 3 ).

Table 4 shows the results of the removal efficiencies average of ammonium, nitrites, nitrates and phosphates in the WTF by type of microalgae and lighting. The microalgae $C$. vulgaris in white light presented the greater removal efficiency of nitrogen compounds. The removal efficiency of nitrite with $83 \%$ reported highest efficiency, followed by nitrates and ammonium (52 and 23\%, respectively). However, higher removal efficiency of phosphates with $66 \%$ was in Multi - LEDs. This result is consistent to what was reported for low densities of

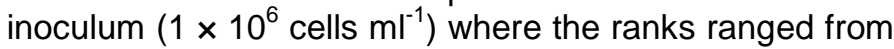
63 to 73\% (Lau et al., 1995; Jiménez del Río, 1996; Neori et al., 2004; Hanumantha-Rao et al., 2010).

On the other hand, in terms of energy consumption, the treatment with multi-LEDs had an approximate consumption of $79.88 \mu \mathrm{mol} \mathrm{m}^{-2} \mathrm{~s}^{-1}$ (light intensity), which would amount to $18.94 \mathrm{~W} \mathrm{~m}^{-2}$, taking as summarized data of equivalence to $1800 \mu \mathrm{mol} \mathrm{m}^{-2} \mathrm{~s}^{-1} \equiv 427 \mathrm{~W} \mathrm{~m}^{-2}$ (Gal et al., 1999).

Comparing energy consumption by type of lighting, white lights was higher than multi-LEDs (40 and $18.94 \mathrm{~W}$, respectively). The photobioreactors operated for 10 days, reached an approximate consumption of 9.6 and 4.32 $\mathrm{kWh}$ for white light and multi-LEDs, respectively. The biomass productivity (Table 2) for $C$. vulgaris in both BBM and WTF, stationary phase, multi-LED was of 0.0854 and $0.0456 \mathrm{~g} \mathrm{l}^{-1} \mathrm{~d}^{-1}$, respectively. Therefore, the biomass productivity in 10 day of operation of the photobioreactors ( 6 I by reactor) was of 5.12 and $2.74 \mathrm{~g}$ for BBM and 
Table 3. Percent composition (\%) of fatty acids in the lipid fraction extracted from Nannochloris oculata and Chlorella vulgaris grown in photobioreactors in WTF and BBM under two lighting conditions (multi-LED and white light).

\begin{tabular}{|c|c|c|c|c|c|c|c|c|c|}
\hline \multirow{3}{*}{ Fatty acid } & \multirow{3}{*}{ Fatty acid } & \multicolumn{8}{|c|}{ Treatments } \\
\hline & & $\begin{array}{c}N^{\mathrm{e}}-\text {-LED }^{\mathrm{a}}- \\
\text { WTF }^{\mathrm{c}}\end{array}$ & $\begin{array}{c}\text { Nn-LED- } \\
\text { BBM }^{\text {d }}\end{array}$ & $\begin{array}{c}\text { Nn-WL }{ }^{b}- \\
\text { WTF }\end{array}$ & $\begin{array}{l}\text { Nn-WL- } \\
\text { BBM }\end{array}$ & $\begin{array}{c}\text { Ch }^{f} \text {-LED- } \\
\text { WTF }\end{array}$ & $\begin{array}{c}\text { Ch-LED- } \\
\text { BBM }\end{array}$ & $\begin{array}{c}\text { Ch- WL - } \\
\text { WTF }\end{array}$ & $\begin{array}{c}\text { Ch- WL- } \\
\text { BBM }\end{array}$ \\
\hline & & \multicolumn{7}{|c|}{ (\%) } & \\
\hline Lauric acid & C12:0 & 0.00 & 0.00 & 0.00 & 0.00 & 0.00 & 0.00 & 0.00 & 0.00 \\
\hline Myristic acid & C14:0 & 0.67 & 0.00 & 0.00 & 0.00 & 0.00 & 0.06 & 0.00 & 0.00 \\
\hline Palmitic acid & C16:0 & 11.66 & 1.58 & 12.00 & 9.41 & 8.32 & 6.10 & 1.91 & 7.29 \\
\hline Stearic acid & C18:0 & 6.06 & 1.54 & 16.97 & 8.55 & 19.65 & 2.08 & 10.90 & 3.32 \\
\hline Oleic acid & C18:1 & 13.68 & 6.40 & 18.37 & 9.25 & 14.81 & 13.05 & 7.06 & 7.23 \\
\hline Linoleic acid & C18:2 & 12.15 & 7.98 & 12.83 & 10.26 & 4.55 & 1.92 & 1.44 & 3.78 \\
\hline Linolenic acid & C18:3 & 6.97 & 2.81 & 0.00 & 2.59 & 6.46 & 3.21 & 3.64 & 2.55 \\
\hline Eicosanoic acid & C20:1 & 12.09 & 6.11 & 5.65 & 30.77 & 16.01 & 8.35 & 8.44 & 10.24 \\
\hline \multirow[t]{2}{*}{ Arachidonic acid } & C20:4 & 1.26 & 0.00 & 3.18 & 0.00 & 3.83 & 7.59 & 15.09 & 12.24 \\
\hline & Total & 64.54 & 26.42 & 69.00 & 70.83 & 73.63 & 42.36 & 48.48 & 46.65 \\
\hline
\end{tabular}

${ }^{\mathrm{a}}$ Multi-LED lighting; ${ }^{\mathrm{b}}$ White light; ${ }^{\mathrm{C}}$ wastewater of tilapia farming; ${ }^{\mathrm{d}}$ bold's basal medium; ${ }^{\mathrm{e}}$ Nannochloris oculata; ${ }^{\mathrm{f}}$ Chlorella vulgaris.

Table 4. Removal efficiencies average of nitrogen compounds and phosphate in Chlorella vulgaris and Nannochloris oculata cultured in WTF for both types of lighting.

\begin{tabular}{|c|c|c|c|c|c|c|}
\hline \multirow{2}{*}{\multicolumn{2}{|c|}{ Treatment }} & & \multicolumn{4}{|c|}{ Removal efficiency (\%) } \\
\hline & & & Ammonium & Nitrite & Nitrate & Phosphate \\
\hline \multirow{4}{*}{ WTF } & Multi-LEDs & Chlorella vulgaris & $1.32 \pm 0.26$ & $30 \pm 4$ & 41.73 & $66.33+6.28$ \\
\hline & White light & Chlorella vulgaris & $22.60 \pm 4.12$ & $83 \pm 3.49$ & $51.95 \pm 2.47$ & $45.00 \pm 3.19$ \\
\hline & Multi-LEDs & Nannochloris oculata & $12.50 \pm 2.31$ & $0.00 \pm 0.00$ & $0.00 \pm 0.00$ & $24.96 \pm 5.16$ \\
\hline & White light & Nannochloris oculata & $12.50 \pm 1.89$ & $0.00 \pm 0.00$ & $3.65 \pm 0.15$ & $47.48 \pm 2.91$ \\
\hline
\end{tabular}

WTF, respectively; with energy consumption per gram of 0.84 and $1.6 \mathrm{kWh} \mathrm{g}^{-1}$ in BBM and WTF, respectively. The greatest energy consumption per gram of biomass for $N$. oculata, was in white light in BBM $\left(2.80 \mathrm{~kW} \mathrm{~g}^{-1}\right)$. Comparing the best results among type of lighting in $\mathrm{BBM}$, the requirement of energy per gram of biomass was greater with white light in N. oculata $\left(2.80 \mathrm{kWh} \mathrm{g}^{-1}\right)$. However, comparing by type of lighting in WTF, $N$. oculata presented greater energy consumption per gram in white light than $C$. vulgaris in multi-LEDS (2.80 and 1.6 $\mathrm{kW} \mathrm{g}^{-1}$, respectively).

\section{DISCUSSION}

In this study, microalgae with the highest average density was $C$. vulgaris in BBM with $88.3 \times 10^{6}$ cells $\mathrm{ml}^{-1}$ during 10 days of cultivation, much higher than the densities obtained in the above-mentioned studies. It is important to note that there were higher densities in all of the treatments reported under different lighting conditions (Figure 2).

De-Bashan et al. (2002) conducted studies on cultures of C. vulgaris, Azopirillum brasilense and C. vulgaris/A. brasilense, showed that the highest density was in

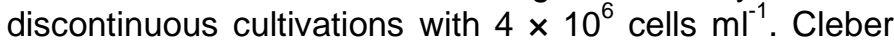
et al. (2008) studied chlorophyll content and profile of minerals in the microalga $C$. vulgaris grown in hydroponic wastewater solution. Cultivations were carried out in BBM as control, concentrations of $100 \%$ hydroponic residual solution (HRS), $50 \%$ residual hydroponic solution and $50 \%$ deionized water (HRS50), $25 \%$ of residual hydroponic solution and $75 \%$ of deionized water (HRS25). The cultivation period was 7 days, obtaining average densities at the end of the period of $10.6 \times 10^{6}$,

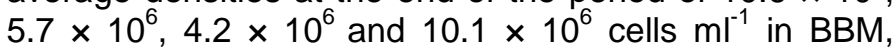
HRS, HRS50 and HRS25, respectively. Furthermore, recent studies to determine the effect that produces leachates of the biosolids on freshwater biota demonstrated an effect on $N$. oculata affecting their growth at concentrations $>500 \mathrm{ppm}$ of leachate after being cultivated with $12 \mathrm{~h}$ light at $31.5 \mu \mathrm{mol} \mathrm{m} \mathrm{m}^{-2}$ and $12 \mathrm{~h}$ dark for 14 days at concentrations of $50,200,500$ and 1000 ppm (Flores et al., 2010). Results indicate that the highest and lowest cell density reached 50 and $500 \mathrm{ppm}$

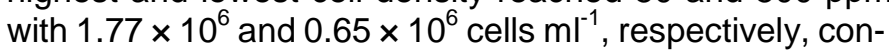


cluding that the leachate can function as fertilizer for the growth of $N$. oculata to concentrations not higher than 50 ppm.

As shown in previous studies, various types of waste are used for the cultivation of $C$. vulgaris and $N$. oculata as culture media. Average cell density at the end of the culture for periods between 7 and 12 days with an initial inoculum of $1.0 \times 10^{6} \mathrm{cells} \mathrm{ml}^{-1}$ was $2.5 \times 10^{6}$ to $10.6 \times$

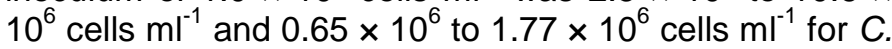
vulgaris and $N$. oculata, respectively.

Mata et al. (2010) remark that, under nitrogen limitation, $C$. vulgaris and $N$. oculata maintained a production of 0.02-0.20 and 0.37-0.48 $\mathrm{g} \mathrm{I}^{-1} \mathrm{~d}^{-1}$, respectively. In addition, the stress situation during cultivation caused the microalgae to generate a higher content of lipids (from 75\%) in comparison to what is expected (20-50\%), with lower biomass productivity $(0.02$ $\left.\mathrm{g} \mathrm{I}^{-1} \mathrm{~d}^{-1}\right)$ in relation to what is expected $\left(0.40 \mathrm{~g} \mathrm{I}^{-1} \mathrm{~d}^{-1}\right)$. In another study, Chiu et al. (2008) reported that in semicontinuous cultures of Chlorella sp. with low and high cell density for $\mathrm{CO}_{2}$ reduction, biomass productivity of $0.037-0.053 \mathrm{~g} \mathrm{I}^{-1} \mathrm{~d}^{-1}$ was obtained; values similar to that obtained in this study for both strains under all culture conditions.

Furthermore, Liang et al. (2009) reported biomass productivity of $0.010-0.254 \mathrm{~g} \mathrm{I}^{-1} \mathrm{~d}^{-1}$ in culture of $C$. vulgaris under growth conditions of heterotrophs, autotrophs and mixotrophs with a maximal lipid content of $38 \%$ under autotrophic conditions. These results, indicate that under conditions of stress due to a low concentration of nitrogen (primarily nitrates), there is an increase in lipid content in biomass at a range of 15 to $58 \%$ (dry weight) depending on the species of microalgae (Mata et al., 2010; Probir et al., 2011; Kirrolia et al., 2013). This behavior was previously observed in other studies (Mata et al., 2010; Kirrolia et al., 2013). Therefore, biomass and lipid productivity can be increased up to $60 \%$ under culture conditions with nitrogen deficiency and high concentrations of $\mathrm{CO}_{2}$ (Chiu et al., 2009; Gouveia and Oliveira, 2009; Liang et al., 2009; Rodolfi et al., 2009; Mata et al., 2010; Borges et al., 2011; Kirrolia et al., 2013).

On the other hand, Guerrero-Cabrera et al. (2014) cultivated three species of microalgae (Monoraphidium SP., Chlorella SP. and Scenedesmus SP.) in three volumes of WTF (1.5, 4 and 9 I, respectively) as culture medium and BBM, and compared the specific rate of growth, volumetric productivity $\left(\mathrm{g} \mathrm{I}^{-1} \mathrm{~d}^{-1}\right)$, biomass productivity $\left(\mathrm{g} \mathrm{l}^{-1}\right)$, as well as protein and lipid content. They reported that Scenedesmus sp. in BBM; it produced a higher specific speed of growth and volumetric productivity $\left(0.332 \mathrm{~g} \mathrm{I}^{-1} \mathrm{~d}^{-1}\right)$ than WTF in $1.5 \mathrm{~L}$ of volume. Also reported was Chlorella $s p$, which also showed a higher lipids volumetric productivity $\left(0.011 \mathrm{~g} \mathrm{~L}^{-1} \mathrm{~d}^{-1}\right)$ for BBM to WTF to $1.5 \mathrm{~L}$ of volume. The maximum lipids concentration in percentage was for Monoraphidium SP. in WTF, $1.5 \mathrm{~L}$ with $17.8 \%$.

Due to its rapid speed of growth and mainly due to its high content of lipids with a rich fraction of saturated and monosaturated fatty acids, preferably C16-C20 polyunsaturated chain, numerous strains of microalgae have been studied as a potential source of triacylglycerides (TAG), the main raw material for biodiesel production (Delrue et al., 2012; Hoekman et al., 2012; Lohrey et al., 2012; Chen et al., 2013; Wei et al., 2013; Singh et al., 2014; Taher et al., 2014).

Some studies have shown that the highest content of lipids present in $N$. oculata and $C$. vulgaris was achieved in nitrogen deficient cultures with a higher content of mono and polyunsaturated fatty acids (Rodolfi et al., 2009; Mata et al., 2010; Kirrolia et al., 2013; Singh et al., 2014; Taher et al., 2014). Therefore, cultures of $N$. oculata illuminated with multi-LEDs and in WTF may be an attractive and economic alternative for the generation of biodiesel due to the high percentage of lipids and mono and polyunsaturated fatty acids.

\section{Conclusion}

The highest biomass productivity and highest cell density was in $C$. vulgaris in BBM and multi-LEDs. $N$. oculata in multi-LEDs reached the highest percentages of lipids in both media. The lipid productivity for both species was variable both for culture medium and lighting condition. Fatty acid composition in the different treatments was mainly saturated, where the highest percentages were in WTF. Based on the results, it is concluded that $N$. oculata and/or C. vulgaris in WTF in multi-LEDs are an economic and sustainable alternative in a scheme of cultivation of microalgae with the greatest potential as a generator of biodiesel.

\section{Conflict of interests}

The authors did not declare any conflict of interests.

\section{ACKNOWLEDGEMENTS}

The authors thank the Director General of Higher Technological Education (DGEST) for the support and financing of the project DGEST: 4237.11-PR 001 and to the National Council of Science and Technology (CONACyT) for the scholarship granted to Yesica I. Ferrer Álvarez, Master's student.

\section{REFERENCES}

Ahmad AL, Yasin NHM, Derek CJC, Lim JK (2011). Microalgae as a sustainable energy source for biodiesel production: A review. Renew Sust. Energ. Rev. 15: 584-593.

Amaro HM, Guedes AC, Malcata FX (2011). Advances and perspectives in using microalgae to produce biodiesel. Appl. Energ. 88: 3402-3410.

Andersen RA (2005). Algal culturing techniques (ed.). Elsevier Academic Press, London. 578 pp. 
Bischoff HW, Bold HC (1963). Phycological studies. IV. Some soil algae from enchanted rock and related algal species. University of Texas Publications. 6318:1-95.

Borges L, Morón-Villarreyes JA, Montes D'Oca MG, Abreu PC (2011). Effects of floculants on lipid extraction and fatty acid composition of the microalgae Nannochloropsis oculata and Thalassiosira weissflogii. Biomass Bioenerg. 35:4449-4454.

Chávez-Crooker P, Obreque-Contreras J (2010). Bioremediation of aquaculture wastes. Curr Opin Biotechnol 21(3):313-317.

Chen CY, Zhao XQ, Yen HW, Ho SH, Cheng CL, Lee DJ, Bai FW, Chang JS (2013). Microalgae-based carbohydrates for biofuel production. Biochem. Eng. J. 78:1-10.

Chisti Y (2007). Biodiesel from microalgae. Biotechnol. Adv. 25:294306.

Chiu SY, Kao CY, Tsai MT, Ong SC, Chen CH, Lin CS (2008). Reduction of $\mathrm{CO}_{2}$ by a high-density culture of Chlorella $s p$. in a semicontinuous photobioreactor. Bioresour. Technol. 99:3389-3396.

Chiu SY, Kao CY, Tsai MT, Ong SC, Chen CH, Lin CS (2009). Lipid accumulation and $\mathrm{CO}_{2}$ utilization of Nannochloropsis oculata in response to $\mathrm{CO}_{2}$ aeration. Bioresour. Technol. 100: 833-838.

Chojnacka K, Marquez-Rocha FJ (2004). Kinetic and stoichiometric relationships of the energy and carbon metabolism in the culture of microalgae. Biotechnol. 3:21-34.

Cleber FB, Ernani SA, Barcelos JL (2008). Chlorophyll content and minerals profile in the microalgae Chlorella vulgaris cultivated in hydroponic wastewater. Ciencia Rural Santa Maria. 38(1): 54-58.

De-Bashan LE, Bashan Y, Moreno M, Lebsky VK, Bustillos JJ (2002). Increased pigment and lipid content, lipid variety, and cell and population size of the microalgae Chlorella spp. when co-immobilized in alginate beads with the microalgae-growth-promoting bacterium Azospirillum brasilenses. Can. J. Microbiol. 48:514-521.

DeJong P, Sánchez AS, Esquerre K, Kalid RA, Torres EA (2013) Solar and wind energy production in relation to the electricity load curve and hydroelectricity in the northeast region of Brazil, Renew. Sust. Energ. Rev 23: 526-535

Delrue F, Setier PA, Sahut C, Cournac L, Roubaud A, Peltier G, Froment AK (2012). An economic, sustainability, and energetic model of biodiesel production from microalgae. Bioresour. Technol. 111:191-200.

Demirbas A (2011). Biodiesel from oilgae biofixation of carbondioxide by microalgae: A solution to pollution problems. Appl. Energ. 88:3541-3547.

Flores JF, Flores L, Valenzuela I, Flores E (2010). Lixiviados de biosolidos sobre la biota dulceacuícola. Investigación y Ciencia de la Universidad Autónoma de Aguascalientes 48:38-43.

Gal G, Loew ER, Rudstam LG, Mohammadian AM (1999). Light and diel vertical migration: spectral sensitivity and light avoidance by Mysis relicta. Can. J. Fish. Aquat. Sci. 56: 311-322.

Gouveia L, Oliveira AC (2009). Microalgae as a raw material for biofue production. J. Ind. Microbiol. Biotechnol. 36: 269-274.

Guerrero-Cabrera L, Rueda JA, García-Lozano H, Navarro AK (2014). Cultivation of Monoraphidium sp., Chlorella sp. and Scenedesmus $s p$. algae in Batch culture using Nile tilapia effluent. Bioresour. Technol. 161: 455-460.

Halim R, Michael D, Paul K, Webley A (2012). Extraction of oil from microalgae for biodisel production: A review. Biotechnol. Adv. 30: 709-732.

Hoekman SK, Broch A, Robbins C, Ceniceros E, Natarajan M (2012). Review of biodiesel composition, properties, and specifications. Renew. Sust. Energ. Rev. 16: 143-169.

Josephine A, Niveditha C, Radhika A, Brindha Shali A, Kumar TS, Dharani G, Kirubagaran R (2015). Analytical evaluation of different carbon sources and growth stimulators on the biomass and lipid productivity of Chlorella vulgaris - Implications for biofuels. Biomass Bioenerg, 75:170-179.
Kirrolia A, Bishnoi NR, Singh R (2013). Microalgae as a boon for sustainable energy production and its future research \& development aspects. Renew. Sustain. Energ. Rev. 20: 642-256.

Lepage G, Roy CC (1984). Improved recovery of fatty acid through direct transesterification without prior extraction of purification. Lipid. Res. 25:1391-1396.

Liang YN, Sarkany N, Cui Y (2009). Biomass and lipid productivities of Chlorella vulgaris under autotrophic, heterotrophic and mixotrophic growth conditions. Biotechnol. Lett. 31: 1043-1049.

Lohrey C, Kochergin V (2012). Biodiesel production from microalgae: Co-location with sugar mills. Bioresour. Technol. 108: 76-82.

Marinho-Soriano E, Azevedo CAA, Trigueiro TG, Pereira DC, Carneiro MAA, Camara MR (2011). Bioremediation of aquaculture wastewater using macroalgae and Artemia. Int Biodeterior Biodegradation 65(1):253-257.

Mata TM, Martins AA, Caetano NS (2010). Microalgae for biodiesel production and other applications: A review. Renew. Sust. Energ. Rev. 14:217-232.

Neori A, Chopin T, Troell MA, Buschmann AH, Kraemer GP, Halling C, Shopigel M, Yarsh C (2004). Integrated aquaculture: rationale, evolution and state of art emphasing seaweed biofiltration in moder mariculture . Aquaculture. 231:361-394.

Nichols HW (1973). Growth media-freshwater. In J. R. Stein (ed.). Handbook of physiological methods II. Cambridge University Press. 7-24.

Pica-Granados Y, Ronco A, Díaz MC (2004). Método de enumeración celular basado en el uso de hemocitómetro Neubauer. In: Castillo, G. (Eds.). Ensayos toxicológicos y métodos de evaluación de calidad de aguas. Estandarización, intercalibración, resultados y aplicaciones. México: IMTA: pp. 54-63

Probir D, Aziz SS, Obbard JP (2011). Two phase microalgae growth in the open system for enhanced lipid productivity. Renew. Energ. 36(9): 2524-2528.

Rodolfi L, Zittelli GC, Bassi N, Padovani G, Biondi N, Bonini G, Tredici MR (2009). Microalgae for oil: strain selection, induction of lipid synthesis and outdoor mass cultivation in a low-cost photobioreactor. Biotechnol. Bioeng. 102: 100-112.

Rosch C, Skarka J, Wegerer N (2012). Materials flow modeling of nutrient recycling in biodiesel production from microalgae. Bioresour. Technol. 107: 191-199.

Sánchez AS, Nogueira IBR, Kalid RA (2015). Uses of the reject brine from inland desalination for fish farming, Spirulina cultivation, and irrigation of forage shrub and crops. Desalination. In press: Available online $27 \quad$ January 2015 http://dx.doi.org/10.1016/j.desal.2015.01.034

Simionato D, Basso S, Giacometti GM, Morosinotto T (2013). Optimization of light use efficiency for biofuel production in algae. Biophysical Chemistry 182:71-78.

Singh J, Gu S (2010). Commercialization potential of microalgae for biofuels production. Renew. Sust. Energ. Rev. 14: 2596-2610.

Singh B, Guldhe A, Rawat I, Buxn F (2014). Towards a sustainable approach for development of biodiesel from plant and microalgae. Renew. Sust. Energ. Rev 29: 216-245.

Taher H, Al-Zuhair S, Al-Marzouqi AH, Haik Y, Farid M (2014). Effective extraction of microalgae lipids from wet biomass for biodiesel production. Biomass Bioenerg. 66:159-167.

Wei L, Huang X, Huang Z, Zhou Z (2013). Orthogonal test design for optimization of lipid accumulation and lipid property in Nannochloropsis oculata for biodiesel production. Bioresour. Technol. 147: 534-538. 